Dicle Tıp Dergisi / Dicle Med J (2019) 46 (4) : 677 - 684

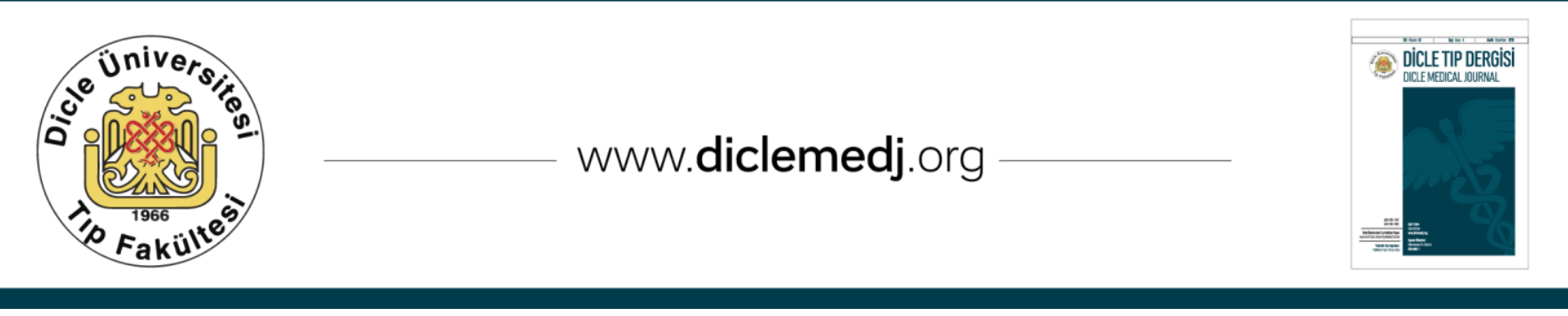

Özgün Araștırma / Original Article

\title{
The Effect of Low Dose Ketamine Infusion on Postoperative Acute and chronic Pain after Thoracotomy
}

\author{
Sibel Seçkin Pehlivan'1, Ayșe Ülgey², Adnan Bayram³ ${ }^{3}$ Cihangir Biçer4, \\ Fahri Oğuzkaya ${ }^{5}$, Adem Boyaci ${ }^{6}$
}

1 Department of Anaesthesiology and Reanimation, Erciyes University, Medical Faculty, Kayseri, Turkey ORCID:0000-0003-3215-5616 2 Department of Anaesthesiology and Reanimation, Erciyes University, Medical Faculty, Kayseri, Turkey ORCID:0000-0002-7634-6214 3 Department of Anaesthesiology and Reanimation, Erciyes University, Medical Faculty, Kayseri, Turkey ORCID: 0000-0002-6700-8301 4 Department of Anaesthesiology and Reanimation, Erciyes University, Medical Faculty, Kayseri, Turkey ORCID:0000-0001-8163-6681 5 Department of Thoracic Surgery, Erciyes University, Medical Faculty, Kayseri, Turkey ORCID:0000-0003-4791-0848

6 Department of Anaesthesiology and Reanimation, Erciyes University, Medical Faculty, Kayseri, Turkey ORCID: 0000-0003-4528-0758

Received: 06.05.2019; Revised: 27.09.2019; Accepted: 10.10.2019

\begin{abstract}
Objective: The aim of this study was to investigate the effects of a perioperatively administered low dose of ketamine on postoperative acute, chronic pain following thoracotomy.

Methods: Forty patients with ASA I-III and aged between 18 and 65 years were included in the study. Patients were randomly divided into two groups. Group I $(\mathrm{n}=20)$ was administered a ketamine $0.5 \mathrm{mg} \cdot \mathrm{kg}^{-1}$ bolus followed by a 2 mcg.kg-1. $\mathrm{dk}^{-1}$ infusion for 24 hours before the incision. Group II $(\mathrm{n}=20)$ was given normal saline at the same dose and duration. Postoperative analgesia was achieved through patient-controlled morphine administration. Postoperative resting and moving Visual Analogue Scale values, total morphine consumption, preoperative and postoperative values of FVC, FEV1 and FEF25-75 from pulmonary function tests were recorded. Patients were evaluated in terms ofchronicpain in the surgical incision area at 1 and 3 months after the operation. Nausea, vomiting, agitation, delirium, hallucination and sedation scores were recorded.

Results: No statistical difference was found between groups in terms of demographic characteristics and operational features. Visual analogue scale values at rest and on movement were significantly lower in Group I. Total morphine consumption was also significantly lower in Group I. There was no difference between the groups in terms of pulmonary function tests. There was no difference between groups in terms of the incidence of chronic pain and development during the first month after the operation, while the incidence of chronic pain in the third month was significantly lower in Group I.No significant difference was observed between groups in terms of sedation scores. The incidence of side effects such as nausea, vomiting, agitation, delirium and hallucinations was similar in both groups.

Conclusion: Low-dose ketamine infusion is an efficient method in postoperative acute and chronic pain management after thoracotomy, it reduces analgesic consumption.
\end{abstract}

Keywords: Ketamine, postoperative analgesia, chronic pain, thoracotomy 


\section{Düşük Doz Ketamin İnfüzyonunun Postoperatif Torakotomi Sonrasi Akut ve Kronik Ağriya Etkisi}

\section{Öz}

Amaç: Torakotomi deperioperatif olarak uygulanan düşük doz ketaminin füzyonunun postoperatif akut, kronik ağrı üzerine etkisi araştırılmıştır.

Yöntemler: ASA I-III, 18-65 yaş, 40 hastada çalışıldı. Hastalar randomize olarak iki gruba ayrıldı. İntraoperatif dönemde insizyondan önce 1. Gruba (Grup I, $\mathrm{n}=20$ ) ketamin $0,5 \mathrm{mg} / \mathrm{kg}$ bolus, idamede $2 \mathrm{mcg}^{\mathrm{kg}}{ }^{-1} \cdot \mathrm{dk}^{-1}$ infüzyon şeklinde 24 saat devam edildi. İkinci gruba (Grup II, $\mathrm{n}=20$ ) aynı dozda ve sürede serum fizyolojik uygulandı. Postoperatif analjezi morfin ile hasta kontrollü analjezi şeklinde uygulandı. Hastaların postoperatif dönemdeki istirahat ve hareketli Görsel Analog Skala değerleri, toplam morfin tüketimi, solunum fonksiyon testlerinden FVC, FEV1 ve FEF25-75'in preoperatif ve postoperatif değerleri kaydedildi. Hastalar operasyondan 1 ve 3 ay sonra cerrahi insizyon alanında kronik ağrı yönünden değerlendirildi. Hastalardaki bulantı, kusma, ajitasyon, deliryum, halusinasyon ve sedasyon skorları kaydedildi.

Bulgular: Demografik özellikler ve operasyonel özellikler açısından gruplar arasında istatistiksel fark bulunmadı. İstirahat ve hareketli dönemdeki Görsel Analog Skala değerleri Grup I'de anlamlı düşüktü. Toplam morfin tüketimi de Grup I'de anlamlı olarak daha düşüktü. Solunum fonksiyon testleri açısından gruplar arasında farklılık yoktu. Kronik ağrının, ağrı skorlamasına göre bir ay sonraki gelişme insidansında gruplar arasında farklılık yokken, 3 ay sonraki gelişme insidansı ağrı skorlamasına göre Grup I'de anlamlı olarak daha düşük bulunmuştur. Sedasyon skorları açısından gruplar arasında anlamlı farklılık yoktu. Bulantı, kusma, ajitasyon, deliryum ve halusinasyon gibi yan etkilerin görülme oranı her iki grupta benzerdi.

Sonuç: Torakotomide düşük doz ketaminin füzyonu postoperatif akut ve kronik ağrı tedavisinde etkili bir yöntemdir, analjezik tüketimini azaltmaktadır.

Anahtar kelimeler: Ketamin, post operatif analjezi, kronik ağrı, Torakotomi.

\section{INTRODUCTION}

Postoperative pain creates distress, depression and anxiety in patients and may result in pathophysiological changes ${ }^{1}$. Thoracotomy is one of the surgical procedures that result in the most severe pain. Post-thoracotomy pain requires significant treatment due to the severity of the complications and the fact that it is among the most severe pains described. Providing efficient postoperative analgesia following thoracotomy is difficult, due to the nociceptive stimuli originating from different points such as the chest wall, organs in the chest cavity, diaphragm and chest tube; softtissue injury during thoracic surgery; visceral damage; and the multiple origins of pain, including bone and joint traumas ${ }^{2}$. Inadequate treatment of the pain which develops following thoracotomy impairs pulmonary function, affecting morbidity and mortality ${ }^{3}$.
Analgesia provided by a single agent for postoperative pain control may not be sufficiently effective. Therefore, multimodal analgesia models in which numerous medications and methods are combined have recently been introduced to postoperative analgesia ${ }^{4,5}$.

Kaur et al. reported that the administration of a high dose of opioids might result in acute tolerance, hyperalgesia and side effects such as sedation, respiratory depression, nausea and emesis ${ }^{3}$. Since N-methyl-D-aspartate (NMDA) receptor activation may enhance acute tolerance against opioids, it was thought that pathological pain and opioid tolerance can be stopped with ketamine, an NMDA receptor antagonist. When ketamine is administered before surgical stimulation, nociceptive stimulation is inhibited. Therefore, if postoperative analgesia could be introduced 
before the trauma, that is if the preemptive agent could be administered, the stress response could be better controlled and analgesic requirements could be kept at a lower level $^{4}$.

Although opioids have a relatively strong analgesic effect, they cannot be used at an effective dose because of the potential side effects that can occur at high doses and the risk of addiction, leading to a failure of postoperative analgesia. Among the opioid agonists, morphine remains the most commonly used agent because of its low cost and minimal cardiovascular side effects ${ }^{1}$.

Post-thoracotomy pain syndrome is defined as the pain that recurs or persists along a thoracotomy incision following the surgical procedure ${ }^{6}$. Post-thoracotomy pain syndrome causes difficulties in the management of pain. Chronic pain occurs secondary to damage or dysfunction of the somatosensory system ${ }^{7}$.

We hypothesized that: 1 . Low dose ketamine will reduce the acute pain after thoracic surgery.2. Low dose ketamine will reduce the chronic pain after thoracic surgery.

The primary objective of this study was to investigate the effect of low-dose ketamine infusion on acute, chronic pain, while the secondary objective was to study its effects on pulmonary function.

\section{METHODS}

Forty patients with ASA I-III, who underwent thoracotomy between the ages of 18 and 65 years were included in this randomized prospective, double blind study. Patients were randomly grouped using the sealed envelope method. This study was approved by the local ethics committee $(\mathrm{No}=2011 / 115)$, and informed consent was obtained from the patients. The study was conducted according to the Declaration of Helsinki.

All of the patients undergoing a standard posterolateral thoracotomy, the skin incision is between 15 and $20 \mathrm{~cm}$ long, depending on the patient's adiposity, and the latissimus dorsi, serratus anterior, and the fifth intercostal muscles are incised. None of the patients undergoing costa resection and none developed rib fractures. Then, uncontrolled hypertension, diabetes mellitus, history of continuous drug use due to chronic pain, psychiatric disorders, opioid addiction, severe liver and/or renal failure and history of allergy against the medications that were used in the study were excluded.

All patients were informed about the visual analogue scale (VAS) [8], and the use of patientcontrolled analgesia (PCA) (HospiraPain Management Pump, HospiraLab, Lake Forest, IL 60045 USA) and spirometry (MIR SPIROBANK Spirometry, ITALY) devices in their preoperative visit.

Once in the operating room, heart rate, peripheral oxygen saturation (SpO2), noninvasive blood pressure, end-tidal carbon dioxide (ETCO2), electrocardiography (ECG) and respiratory rate (RR) were monitored.

After the pre-oxygenation of all patients in the operating room, propofol 2-2.5 mg.kg-1 IV (Propofol 1\% Fresenius, Fresenius Kabi Deutschland, Bad Homburg, Germany) and Fentanyl $2 \mu \mathrm{g} \cdot \mathrm{kg}^{-1}$ were administered IV for anesthetic induction; following muscle relaxation using rocuroniumbromur $0.6 \mathrm{mg} \cdot \mathrm{kg}^{-1}$ IV(EsmeronR, N.V. Organon Kloosterstraat, Holland), orotracheal intubation was performed with double-lumen endobronchial tubes (39-41 French (Fr) tubes for males and 32-36 Fr tubes for females). Maintenance of anesthesia was achieved through sevoflurane 2-3\% (Sevorane, Abbott, England), 50/50\% oxygen-air mixture and a remifentanyl (Ultiva, GlaxoSmithKline, Turkey) infusion. When the mean arterial pressure (MAP) was $20 \%$ greater than the pre-induction values, the dose of remifentanyl infusion was increased. Preparation of the medication to be used in the 
study was performed by an anesthetist who did not take part in intraoperative monitoring. Patients in Group I were given 0.5 mg. $\mathrm{kg}^{-1}$ IV ketamine (Ketalar, Eczacibasi, Luleburgaz, Turkey) diluted with $10 \mathrm{ml}$ of Saline in a bolus dose before the incision, and then $500 \mathrm{mg}$ ketamine (as $1 \mathrm{ml}=2 \mathrm{mg}$ ketamine) was added to $250 \mathrm{ml}$ Saline $250 \mathrm{ml}$ and introduced at a dose of $2 \mu \mathrm{g} . \mathrm{kg}-1 . \mathrm{dk}-1$ through an infusion pump and continued during surgery and the first 24 hours postoperatively. Saline was given to Group II at a similar volume and time as the ketamine application in the study group. Patients in both groups were administered 0.05 mg.kg-1 of morphine $\mathrm{HCl}$ (Morphine, Osel, Turkey) as an IV bolus before awakening. Ondansetron HCL (Zofran, Glaxo Smithkline, Italy) $4 \quad \mathrm{mg} \quad$ IV was administered intraoperatively in all patients.

Once the surgical procedure had terminated, anesthetic maintenance was stopped, and residual blockade was reversed using 0.04 mg.kg-1 neostigmine (Neostigmine, Polifarma, Turkey) and 0.02 mg.kg-1 atropine (Atropin Sulphate, Galen, Turkey) (IV). After ensuring adequate spontaneous breathing tidal volume and sufficient muscle recovery, tracheal extubation was carried out. The patients were then given $100 \%$ oxygen for 5 minutes.

After referral to the recovery unit, PCA was prepared for both groups in the form of morphine programmed as a $1 \mathrm{mg}$ bolus dose with a lockout time of 15 minutes and a maximum four hours limit of $40 \mathrm{mg}$. Patients whose Aldrete Recovery Scores ${ }^{9}$ were higher than 9 were transferred to the thoracic surgery intensive care unit. Patients were monitored for at least 24 hours. The analgesic requirements of both groups were recorded as morphine consumption and additional analgesic requirements from the patientcontrolled analgesia.

The postoperative VAS scores and morphine consumption by the patients were evaluated and recorded at 2,6,12 and 24 hours postoperatively. If VAS was $>4$, dexketoprofen trometamol (Aerveles, Vem, Turkey) was infused as a rescue analgesic, and if VAS scores remained higher than 4, Paracetamol (Parol, Atabay, Kadıkoy, Istanbul) 1gr IV was infused.

ASA value, surgical procedure and time of operation were recorded for each patient. Itching, respiratory distress, mental status changes (agitation, delirium and hallucinations), nausea and vomiting were recorded. Nausea and vomiting were assessed using a four-point categorical scale $(0=$ no nausea, $1=$ mild nausea, $2=$ severe nausea, $3=$ nausea leading to vomiting). Sedation score was evaluated with Ramsey sedation Score system (9). Metoclopramide $\mathrm{HCl}$ (Primperan, Menta, Turkey) $10 \mathrm{mg}$ IV was available in the postoperative period in the case of nausea and/or vomiting. Patients were evaluated chronic pain at 1 and 3 months after the operation?. If the patient has got pain at surgical side, they were regarded as 'chronic pain patients'.

Pulmonary function tests were carried out in the preoperative period and 72nd postoperative hour. In the postoperative period, the reference values of forced vital capacity (FVC), forced expiratory volume in the first second (FEV1) and forced expiratory flow at $25-75 \%$ of the total volume (FEF25-75) were measured with the patients in the sitting position. The mean value of measurements with variation below $10 \%$ among three consecutive measurements was recorded as the baseline value. 
Table I: Operation features (number of cases) of the groups

\begin{tabular}{lcc}
\hline Surgeryto be performed & $\begin{array}{c}\text { Group I } \\
(\mathrm{n}=20)\end{array}$ & $\begin{array}{c}\text { Group II } \\
(\mathrm{n}=20)\end{array}$ \\
\hline $\begin{array}{l}\text { Lung resection and } \\
\text { pneumonectomy }\end{array}$ & 0 & 9 \\
\hline Biopsy & 5 & - \\
\hline Decortication & 3 & 4 \\
\hline Wedgeresection & 2 & - \\
\hline Bulla excision & 2 & 2 \\
\hline Massexcision & 1 & - \\
\hline Cystexcision & - & 5 \\
\hline
\end{tabular}

Group I, Ketamine group; Group II, Control group.

All statistical analyses were performed using SPSS (Statistical Package for Social Science using package version 15.0) (SPSS, Inc., Chicago, IL, USA).The Chi-square test was used to compare qualitative measurements (gender, additional need for analgesia and side effects such as nausea, vomiting, agitation, delirium, hallucination), while the Student t-test was used to compare quantitative data (age, weight) in the case of a normal distribution and the Mann-Whitney U-test in the case of a nonnormal distribution (VAS, sedation score, morphine dose and comparison of pulmonary function tests). Kosucu et al. (7), estimated opioid was decreased $20 \%$ from $44 \pm 11 \mathrm{mg}$ in the 24 hours following operation. Using this estimate, and $\alpha=0.05$ and $\beta=0.20$, the proposed sample size of 20 patients per group was expected to be adequate to detect these data, through power analysis using a sample size software (version 10.1.6,1993-2009 MedCalc Software, Mariakerke, Belgium).

\section{RESULTS}

Operation features (number of cases) of the groups are given in Table 1 . No significant difference was found between groups in terms of the demographic data ( $p>0.05$, Table 2$)$.

Table II: Demographic Data of the Groups

\begin{tabular}{|lllc|}
\hline & $\begin{array}{l}\text { Group I } \\
(\mathrm{n}=20)\end{array}$ & $\begin{array}{l}\text { Group II } \\
(\mathrm{n}=20)\end{array}$ & $\mathrm{p}$ \\
\hline Age (year) & $50.15 \pm 10.23$ & $45.5 \pm 10.99$ & 0.162 \\
Gender (F/M) & $4 / 16$ & $7 / 13$ & $0.288^{*}$ \\
Weight (kg) & $76.10 \pm 11.91$ & $70.9 \pm 10.99$ & 0.160 \\
ASA (I, II, III) & $6 / 13 / 1$ & $8 / 11 / 1$ & 0.314 \\
Surgery time (min) & $167.5 \pm 52.17$ & $151.75 \pm 42.68$ & 0.369 \\
\hline
\end{tabular}

Group I, Ketamine group; Group II, control group. Data shows the number of cases or mean \pm SD. P-values calculate during Student $t$-test and $\mathrm{p}<0.05$ value is considered as significant.* $\mathrm{P}$ -value calculated using chi-square test.

Table III: Chronic Pain Outcomes of the Groups (Case Number)

\begin{tabular}{|l|l|l|l|l|l|l|l|}
\hline & \multicolumn{3}{|c|}{ Group I (n=20) } & \multicolumn{4}{c|}{ Group II (n=20) } \\
\hline & \multicolumn{3}{|c|}{$\begin{array}{c}\text { Chronicity (+) } \\
\text { Chronicity (-) }\end{array}$} & \multicolumn{4}{c|}{$\begin{array}{c}\text { Chronicity (+) } \\
\text { Chronicity (-) }\end{array}$} \\
\hline & $\mathrm{n}$ & $\%$ & $\mathrm{n}$ & $\mathrm{n}$ & $\%$ & $\mathrm{n}$ & $\mathrm{p}$ \\
\hline Month 1 & 3 & 15 & 17 & 8 & 40 & 12 & 0.155 \\
\hline Month 3 & 1 & 5 & 19 & 10 & 50 & 10 & $0.003^{*}$ \\
\hline
\end{tabular}

${ }^{*} \mathrm{p}<0.05$ was considered as significant.

VAS values obtained at rest and on movement were significantly lower in Group I at 2, 6, 12 and 24 hours period $(\mathrm{p}=0.017,0.001,0.003$, 0.04 respectively at rest and $\mathrm{p}=0.007,0.001$, $0.001,0.003$ at movement respectively) (Figures 1,2).

Morphine consumption in postoperative 12-24 hours $(p=0.001)$, and total morphine consumption were found to be significantly lower in Group I ( $p=0.018)$ (Figure 3). 


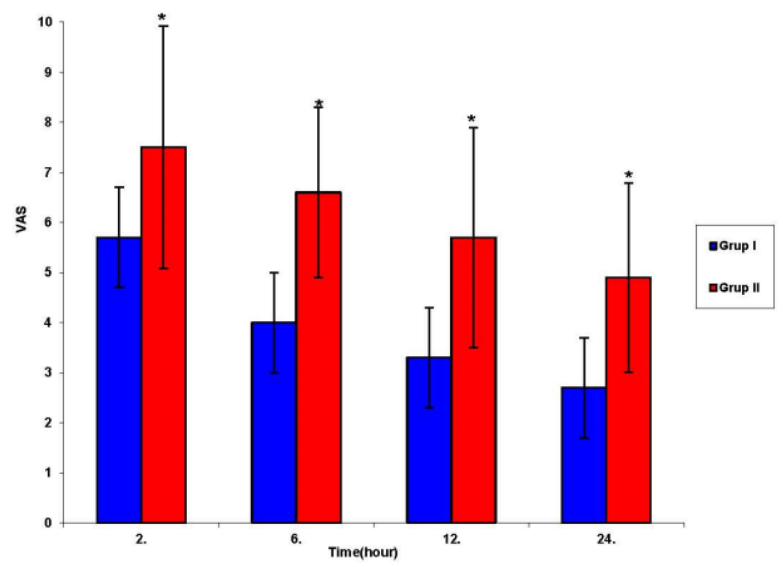

Figure1. The VAS Values of The Groups at Rest

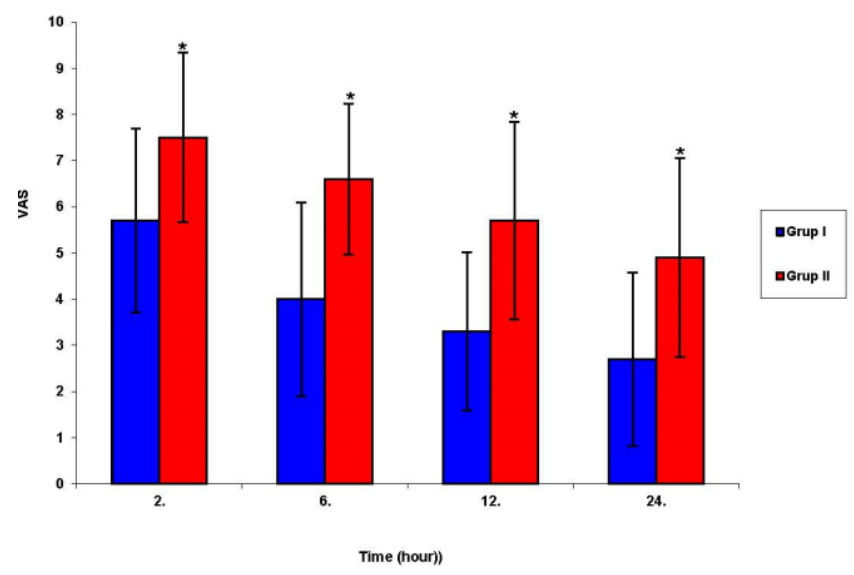

Figure 2. The VAS Values of The Groups on Cough

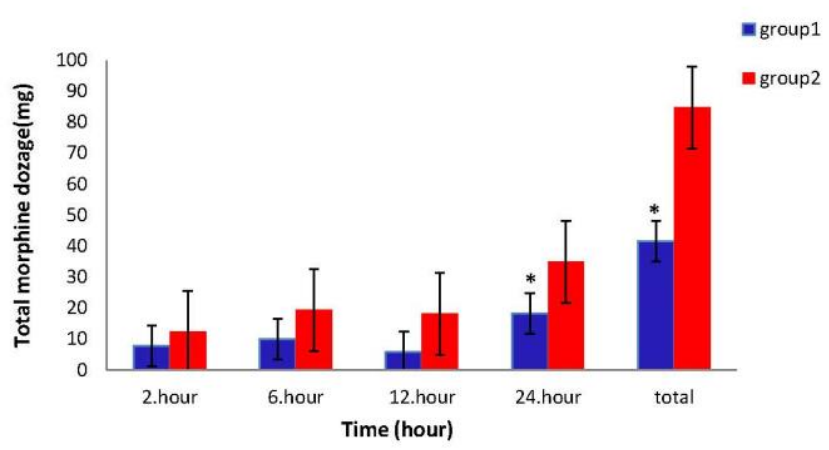

Figure 3.The Morphine Sülphate Consumption of the Groups

When baseline values and FEV1, FVC and FEF25-75 values at 72 hours postoperatively were compared, no significant difference was found between groups ( $\mathrm{p}>0.05)$.

No difference was found in the incidence of chronic pain development between groups in the first month, while this incidence was lower in the third month in Group I ( $\mathrm{p}=0.003$, Table 3). No statistically significant difference was observed between groups in terms of sedation scores $(\mathrm{p}>0.05)$.

Only mild nausea was seen in one patient in Group I and three patients in Group II ( $p$ > 0.05). There were no reports of hallucinations, delirium or respiratory depression in either group.

\section{DISCUSSION}

In this study, we demonstrated that ketamine given in addition to postoperative i.v. PCA morphine provided acute and chronic pain following thoracotomy. Then we found that the combination of ketamine with morphine reduced both VAS values, morphine consumption, acute and chronic pain.

The administration of a sub-anesthetic dose of ketamine is known to be an efficient method of pain control. It is clear that high-dose ketamine is an anesthetic agent and low-dose ketamine is anti-hyperalgesic; its separation should be clearly made. Ketamine has a third dose sequence; if ketamine is used with an opioid, its analgesic activity increases ${ }^{10}$. Tucker et al. ${ }^{11}$ reported that the use of low-dose ketamine (serum ketamine 30-120 ng.ml ${ }^{-1}$ ) increases the analgesic effect without any side effects when combined with $\mu$ opioid agonists in clinical applications. In addition, the combination of ketamine with 1-6 $\mu \mathrm{g} . \mathrm{kg}^{-1} \mathrm{~min}^{-1}$ infusion has an analgesic and opioid-reducing effect. Therefore, in this study, after administering ketamine as a bolus dose of $0.5 \mathrm{mg} \cdot \mathrm{kg}^{-1}$, we gave it as a continuous infusion at $2 \mu \mathrm{g} . \mathrm{kg} \cdot{ }^{-1} \mathrm{~min}^{-1}$ and introduced ketamine application before the surgical stimulant as in the previous study. 
The total morphine dose used in patients who had Group II was significantly lower than the Group I. These results are consistent with studies by Remerand and Suppa et al.12,13. In contrast to our study, Jakschet al. ${ }^{14}$ used 2 $\mu \mathrm{g} . \mathrm{kg} \cdot{ }^{-1} \mathrm{~min}^{-1}$ doses of infusion in knee arthroscopic surgery by using $0.5 \mathrm{mg} . \mathrm{kg} .^{-1}$ bolus doses of ketamine; this was found to not be effective in postoperative pain, because they administered the ketamine infusion only 2 hours after the operation. However, in our study, the infusion was continued for a 24 hour postoperative period.

One of the objectives of the management of postoperative pain in thoracic surgery is to prevent the development of chronic pain. The incidence of chronic pain increases after postoperative pain, which is not controlled in the early period ${ }^{15}$. The activity of nociceptors increases with the damage of the tissues and this causes the release of Substance P, Calcitonin gene related peptides and glutamate. The nociception causes the release of NMDA receptors by stimulation ${ }^{16,17}$. This leads to chronic pain. The effect of ketamine is introduced at this phase as an NMDA receptor antagonist. Ketamine modulates central sensory processing of pain ${ }^{16,17}$.

Cogan et al. ${ }^{18}$ studied IV Ketamine infusion at $200 \mu \mathrm{g} . \mathrm{kg}^{-1} \mathrm{~h}^{-1}$ on post-cardiac surgery pain for 48 hours. In postoperative months 3,9 and 13 , they evaluated chronic pain and found no difference between patients and the control group. In our study, at 1 st month Group I chronicity of pain development rate is $15 \%$, while Group II has $40 \%$. This evaluation of pain is not clinically significant but is clinically meaningful. Chronic pain in the third month development were statistically and clinically significant in Group I. We started the ketamine infusion in the perioperative period; therefore, preemptive analgesia may diminish central sensitization.
Following thoracic surgery, pulmonary dysfunction may develop due to a reduced lung volume. The efficient treatment of postthoracotomy pain which leads to a marked reduction in postoperative pulmonary function is crucial for the protection of pulmonary function and to minimize dysfunction ${ }^{8,19}$. Michele et al. ${ }^{20}$ compared the effects on pulmonary function by adding ketamine from PCA to morphine after thoracic surgery. FEV1 and FVC were decreased in the ketamine group. In the current study, no significant difference in FVC, FEV1 and FEF25-75 preoperatively or 72 hours postoperatively was observed between groups. When each group was compared with the baseline values, a positive difference was found in the ketamine group; however, this difference was not statistically significant.

In the present study, we did not encounter side effects such as vomiting, delirium or hallucinations in any group. This might be attributed to the low dose of ketamine, which we administered at a level that would not produce psychomimetic side effects, and the lower dose of morphine required when administered with ketamine.

The effect of Ketamine on postoperative pain is well known, but the effects on chronic pain are unknown. The limitation of this study is the number of patients analyzed at 1 and 3 months after surgery, because this was a small group in which to evaluate chronic pain.

In conclusion, we found that ketamine infusion introduced following thoracotomy surgery and continued at a low dose for 24 hours postoperatively was an effective and useful method for acute and chronic pain treatment.

Funding Statement: This study was not financed by any institution.

Declaration of Conflicting Interests: The authors declare that they have no conflict of interest. 


\section{REFERENCES}

1. Radvansky B. M, Shah K, Parikh A, et al. Role of Ketamine in Acute Postoperative Pain Management: A Narrative Review. Biomed Res Int 2015; 10: 1-14.

2. Yakşi E, Yakşi O. Current treatment options for postthoracotomy pain syndrome: a review. CurrThoracSurg 2017; 2: 103-10.

3. Kaur S, Saroa R and Aggarwal R. Effect of intraoperative infusion of low-dose ketamine on management of postoperative analgesia. J Nat SciBiol Med. 2015; 6: 378-82.

4. Jain R and Kochhar N. Influence of Difference in Timing of Perioperative Administration of Low-dose Ketamine on Postoperative Analgesia. Anesth Essays Res. 2017; 11: 406-10.

5. Pınar A, Hepağuşlar H, Pınar U, et al. The effect of intercostal nevre block on epidural analgesia in patients under going thoracotomy. Turkish J ThoracCardiovascSurg 2012; 20: 94-100.

6. Della Corte F, Mendola C, Messina A, Cammarota G. Post thoracotomy pain syndrome. Front Lines of Thoracic Surgery. 2012; 391- 400.

7. Koşucu M, Tuğcugil E, Ertürk E, et al. The effects of the pre-emptive oral gabapentin on post-anesthesia recovery criteria, acute post-thoracotomy pain and development of chronicity in pain with benign thoracotomy operations. Turkish J ThoracCardiovascSurg 2014; 22: 389-96.

8. Ye F, Wu Y, Zhou C. Effect of intravenous ketamine for post operative analgesia in patients under going laparoscopic cholecystectomy A meta-analysis. Medicine 2017; 96: 51.

9. Aitkenhead AR. Analgesia and sedation in intensivecare. Br Anaesth 1989; 63: 196-206.

10. Himmelseher S, Durieux M.E. Ketamine for Perioperative Pain Management. Anesthesiology 2005; 102: 211-20.

11. Tucker AP, Kim YI, Nadeson R, Goodchild CS. Investigation of the potentiation of the analgesic effects of fentanyl by ketamine in humans: a double-blinded, randomised, placebo controlled, cross overstudy of experimental pain. BMC Anesthesiol 2005; 5: 2.
12. Remerand F, Le Tendre C, Baud A, et al. The early and delayed analgesic effects of ketamine after total hip arthroplasty: a prospective, randomized, controlled, double-blind study. AnesthAnalg 2009; 109: 1963-71.

13. Suppa E, Valente A, Catarci S, et al. A study of lowdose S-ketamine infusion as 'preventive' pain treatment for cesarean section with spinal anesthesia: benefits and side effects. Minerva Anestesiologica. 2012; 78: 774-81.

14. Jaksch W, Lang S, Reichhalter R, et al. Perioperative small-dose $S \quad(+)$-ketamine has no incremental beneficial effects on postoperative pain when standardpractice opioid infusions are used. AnesthAnalg 2002; 94: 981-6.

15. Humble S.R, Dalton A.J, Li L. A systematic review of therapeutic interventions to reduce acute and chronic post-surgical pain after amputation, thoracotomy or mastectomy. Eur J Pain 2015; 19: 451-65.

16. Chin E, Wann J, Valchanov K. Pharmacological Management of Post-thoracotomy Pain. Open Med J 2016; 3: 255-64.

17. Mesbah A, Yeung J, Gao F. Pain after thoracotomy. BjaEduc 2015; 16: 1-7.

18. Cogan J, Lalumiere G, Vargas G, et al. Low-dose Intravenous Ketamine for Postcardiac Surgery Pain. Effect on Opioid Consumption and the Incidence of Chronic Pain. Annals of Cardiac Anaesthesia 2017; 20: 4.

19. Subramaniam K, Subramaniam B, Steinbrook RA. Ketamine as adjuvant analgesic to opioids: a quantitative and qualitative systematic review. AnesthAnalg 2004; 99: 482-9.

20. Michelet P, Guervilly C, Hélaine A, et al. Adding ketamine to morphine for patient controlled analgesia after thoracic surgery: influence on morphine consumption, respiratory function, and nocturnal desaturation. Br J Anaesth 2007; 99: 396-403. 